\title{
Relationships between Plant Diversity and Grasshopper Diversity and Abundance in the Little Missouri National Grassland
}

\author{
David H. Branson \\ USDA-Agricultural Research Service, Northern Plains Agricultural Research Laboratory, Sidney, MT 59270, USA \\ Correspondence should be addressed to David H. Branson, dave.branson@ars.usda.gov \\ Received 31 May 2010; Revised 25 September 2010; Accepted 5 November 2010 \\ Academic Editor: Michael Sergeev \\ Copyright () 2011 David H. Branson. This is an open access article distributed under the Creative Commons Attribution License, \\ which permits unrestricted use, distribution, and reproduction in any medium, provided the original work is properly cited.
}

A continuing challenge in orthopteran ecology is to understand what determines grasshopper species diversity at a given site. In this study, the objective was to determine if variation in grasshopper abundance and diversity between 23 sites in western North Dakota (USA) could be explained by variation in plant species richness and diversity. In this system with relatively low plant diversity, grasshopper species richness and abundance were not significantly associated with plant species richness in either year. Although a number of significant associations between plant diversity and grasshopper diversity were found through regression analyses, results differed greatly between years indicating that plant species richness and diversity did not lead to strong effects on grasshopper diversity metrics. Plant species richness appears to be too coarse grained to lead to accurate predictions of grasshopper species richness in this system dominated by generalist grasshopper species.

\section{Introduction}

Grassland insect diversity is often linked to plant species composition and habitat structure [1-4]. Several general hypotheses have been proposed to explain relationships between plant and herbivore species richness $[5,6]$, with insect herbivore diversity often thought to generally increase with increased plant species richness due to increased resource diversity $[3,5]$. Although habitat associations with grasshoppers have been studied since the early 1900s [7], it remains a continuing challenge in grasshopper ecology to understand patterns of species diversity $[4,8]$. Numerous factors could influence grasshopper species diversity including resource availability, habitat structure, escape space, and predators $[4,9,10]$. Furthermore, management practices such as livestock grazing and fire impact plant species composition and subsequently affect grasshopper species composition $[4,11]$. Many studies have examined relationships between grasshopper community composition and vegetation patterns in grassland ecosystems worldwide (e.g., $[2,4,8,12-14])$. Plant diversity often positively affects grasshopper species diversity, but relationships are not consistent. Additionally, grasshopper feeding patterns can have important impacts on local plant abundance and community structure [15-17]. In most grassland ecosystems the nature of relationships between plant species richness and grasshopper abundance and diversity remains unclear $[3,4]$.

Grasshoppers are often the dominant native herbivore in grassland ecosystems worldwide, with widespread economically damaging grasshopper outbreaks occurring frequently in western North America $[11,15]$. Despite the economic importance of grasshoppers in the area of this study, the northern Great Plains [18, 19], relationships between plant diversity and grasshopper diversity and abundance are not clearly defined. In contrast to the majority of herbivorous insects, most grasshopper species tend to be generalist feeders that consume a variety of unrelated plant species $[20,21]$. As a result, relationships between plant species richness and grasshopper species richness could be weaker in grass dominated ecosystems with numerous grass or mixed feeding generalist grasshoppers. The objective of this study was to determine if variation in grasshopper abundance and diversity between 23 sites in western North Dakota (US) could be explained by variation in plant species richness and diversity. 
TABle 1: Characteristics of each site in western North Dakota.

\begin{tabular}{|c|c|c|c|c|c|c|}
\hline \multirow{2}{*}{ Site } & \multirow{2}{*}{ Elevation (m) } & \multirow{2}{*}{ Coordinates } & \multicolumn{2}{|c|}{ Plant species } & \multicolumn{2}{|c|}{ Grasshopper species } \\
\hline & & & 2001 & 2002 & 2001 & 2002 \\
\hline Charbonneau & 689 & $47^{\circ} 46^{\prime} 33 \mathrm{~N} 103^{\circ} 49^{\prime} 30 \mathrm{~W}$ & 11 & 6 & 19 & 19 \\
\hline Cheney & 603 & $47^{\circ} 44^{\prime} 29 \mathrm{~N} 104^{\circ} 01^{\prime} 35 \mathrm{~W}$ & 5 & 8 & $*$ & 16 \\
\hline Devitt & 600 & $47^{\circ} 38^{\prime} 37 \mathrm{~N} 104^{\circ} 01^{\prime} 53 \mathrm{~W}$ & 12 & 7 & 18 & 14 \\
\hline East & 710 & $47^{\circ} 36^{\prime} 35 \mathrm{~N} 103^{\circ} 56^{\prime} 09 \mathrm{~W}$ & 8 & 7 & 13 & 18 \\
\hline Plant & 609 & $47^{\circ} 38^{\prime} 05 \mathrm{~N} 104^{\circ} 01^{\prime} 08 \mathrm{~W}$ & 8 & 5 & 17 & 16 \\
\hline Jacobson5A & 690 & $47^{\circ} 48^{\prime} 04 \mathrm{~N} 103^{\circ} 48^{\prime} 31 \mathrm{~W}$ & 6 & 5 & 19 & 24 \\
\hline Klandl & 667 & $47^{\circ} 38^{\prime} 27 \mathrm{~N} 103^{\circ} 57^{\prime} 24 \mathrm{~W}$ & 5 & 6 & 19 & 27 \\
\hline IndergardN & 675 & $47^{\circ} 35^{\prime} 14 \mathrm{~N} 103^{\circ} 49^{\prime} 39 \mathrm{~W}$ & 8 & 7 & 15 & 13 \\
\hline IndergardS & 730 & $47^{\circ} 34^{\prime} 43 \mathrm{~N} 103^{\circ} 50^{\prime} 46 \mathrm{~W}$ & 7 & 6 & 23 & 22 \\
\hline Rau & 757 & $47^{\circ} 42^{\prime} 08 \mathrm{~N} 103^{\circ} 57^{\prime} 15 \mathrm{~W}$ & 11 & 9 & 14 & 20 \\
\hline Saltwell & 751 & $47^{\circ} 36^{\prime} 32 \mathrm{~N} 103^{\circ} 56^{\prime} 05 \mathrm{~W}$ & 5 & 8 & 15 & 24 \\
\hline SD101 & 700 & $47^{\circ} 33^{\prime} 23 \mathrm{~N} 104^{\circ} 00^{\prime} 21 \mathrm{~W}$ & 8 & 5 & 17 & 18 \\
\hline 101 Creek & 654 & $47^{\circ} 33^{\prime} 44 \mathrm{~N} 104^{\circ} 00^{\prime} 30 \mathrm{~W}$ & 9 & 8 & 11 & 18 \\
\hline SM02 & 686 & $47^{\circ} 39^{\prime} 28 \mathrm{~N} 103^{\circ} 51^{\prime} 18 \mathrm{~W}$ & 5 & 4 & 19 & 20 \\
\hline SM05B & 740 & $47^{\circ} 37^{\prime} 42 \mathrm{~N} 103^{\circ} 45^{\prime} 45 \mathrm{~W}$ & 10 & 7 & 20 & 21 \\
\hline SM05NB & 747 & $47^{\circ} 37^{\prime} 03 \mathrm{~N} 103^{\circ} 45^{\prime} 58 \mathrm{~W}$ & 10 & 8 & 21 & 20 \\
\hline SM07B & 655 & $47^{\circ} 36^{\prime} 54 \mathrm{~N} 103^{\circ} 48^{\prime} 54 \mathrm{~W}$ & 8 & 9 & 13 & 19 \\
\hline SM11 & 708 & $47^{\circ} 43^{\prime} 37 \mathrm{~N} 103^{\circ} 52^{\prime} 24 \mathrm{~W}$ & 8 & 9 & 21 & 20 \\
\hline SM12 & 719 & $47^{\circ} 43^{\prime} 55 \mathrm{~N} 103^{\circ} 50^{\prime} 46 \mathrm{~W}$ & 7 & 5 & 13 & 19 \\
\hline SM13 & 704 & $47^{\circ} 43^{\prime} 11 \mathrm{~N} 103^{\circ} 49^{\prime} 05 \mathrm{~W}$ & 7 & 9 & 17 & 18 \\
\hline Shadwell & 717 & $47^{\circ} 26^{\prime} 03 \mathrm{~N} 104^{\circ} 02^{\prime} 30 \mathrm{~W}$ & 8 & 5 & 18 & 19 \\
\hline Whited & 703 & $47^{\circ} 28^{\prime} 36 \mathrm{~N} 104^{\circ} 04^{\prime} 21 \mathrm{~W}$ & 8 & 7 & 15 & 16 \\
\hline Windmill & 658 & $47^{\circ} 39^{\prime} 07 \mathrm{~N} 104^{\circ} 00^{\prime} 11 \mathrm{~W}$ & 3 & 4 & 15 & 20 \\
\hline
\end{tabular}

\section{Materials and Methods}

The study was conducted on the Little Missouri National Grasslands in western North Dakota (USA), managed as part of the United States Forest Service Dakota Prairie Grasslands. The area of the study is characterized by wide summits and networks of gullies [22]. The historic plant community is a mixed grass prairie dominated by grasses including western wheatgrass (Pascopyrum smithii), blue gramma (Bouteloua gracilis), needle and thread (Hesperostipa comata), and green needlegrass (Nassella viridula). The region is semiarid and receives approximately $355 \mathrm{~mm}$ to $400 \mathrm{~mm}$ of precipitation annually; most of which occurs during the growing season. Mean daily temperatures range from $-17.2^{\circ} \mathrm{C}$ in winter to $29.4^{\circ} \mathrm{C}$ in summer. Precipitation measured at a nearby weather station during the growing season of 2001 was slightly above, while precipitation during 2002 was slightly below the long-term average.

During the spring and early summer of 2001, 23 sites were established in the Little Missouri National Grassland. The sites were located within $35 \mathrm{~km}$ of each other, ranged in elevation from 600 to $751 \mathrm{~m}$, and were randomly chosen to include a range of grassland habitat types (Table 1). Nearly all sites were dominated by native vegetation. At each site, a $10 \mathrm{~m}$ by $10 \mathrm{~m}$ subplot was established for sampling vegetation species composition and grasshopper densities. Grasshopper population densities were determined by counting the number of grasshoppers that flushed from within $20,0.1 \mathrm{~m}^{2}$ aluminum wire rings, following the methods of Onsager and Henry [23]. Rings were arranged in a grid of four rows, with 5 rings per row, and held in place by landscape staples. Sites were sampled for grasshopper population densities and species composition four times in 2001 and six times in 2002, between the last week of June and the first week of September. Sampling took place when air temperature was greater than $23^{\circ} \mathrm{C}$. A sweep net sample was taken, using an insect aerial net with a four foot handle, in the vegetation surrounding the $10 \mathrm{~m}$ by $10 \mathrm{~m}$ sampling plot to establish grasshopper community composition. Vegetation structure was dominated by grasses and forbs, with few shrubs. An equal number of 150 sweeps were taken while walking slowly that rubbed on the soil surface and that passed through the vegetation canopy while walking rapidly [24]. Sweep net samples were frozen, and grasshoppers were later identified to species in the laboratory. To adjust for differences in sweep net sample sizes between sites, individual species densities were estimated by combining the percentage composition in sweep samples with grasshopper densities from ring counts.

Vegetation species composition was examined in early July 2001 and 2002. Each side of the sampling site served as a $10 \mathrm{~m}$ transect with a fifth transect in the middle of the plot, with 500 sampling points per site. Along each transect, every one meter a standard 10-pin frame was used to determine vegetation composition based on the total number of contacts by a pin. A contact was considered as the pin point coming into contact with the basal area of a 
plant, bare ground, or litter. Across both years of sampling, western wheatgrass was a dominant or codominant grass at 14 sites, blue grama at 13 sites, junegrass at eight sites, threadleaf sedge at three sites, needle and thread at two sites, crested wheatgrass (Agropyron cristatum) at two sites, green needlegrass at one site, and Kentucky bluegrass (Poa pratensis) at one site. For each site, total plant species richness, proportional coverage of live vegetation, and plant diversity were calculated.

Relationships between insect species diversity and plant diversity could differ seasonally but were not assessed in this study. As grasshopper sample sizes were low in some sweep net samples from sites with low population densities, all sweep samples were pooled prior to analysis to reduce error [24], increase the probability that rare grasshopper species would be incorporated [5], and better account for varying grasshopper phenologies [2]. Grasshopper abundance data was also averaged across sample periods within a year to reduce the influence of random sampling variation when few individuals are detected in density subsamples [25]. Data was transformed as needed. The majority of grasshopper species present at the sites overwinter as eggs and hatch in late spring or early summer; however four nymphoverwintering grasshopper species that hatch in late summer and become adults in the spring were caught in sweep samples. Only egg-overwintering grasshopper species were included in the analysis, as plant-grasshopper relationships would be expected to differ due to the divergent phenologies of these two groups. Patterns of grasshopper species diversity were examined using numerical species richness, Shannon index of species diversity, and Simpson evenness index [26]. Regression analyses were conducted to examine habitat variables responsible for grasshopper abundance and diversity. Systat 12 (Systat Software Inc.) was used for all analyses.

\section{Results and Discussion}

Cumulative plant species richness was relatively low, with a total of 31 species detected across all sites. Mean plant species richness was 7.24, with a maximum species richness of 12 species at a site (Table 1). Forb species richness ranged from zero to six species, while grass species richness ranged from two to seven. Vegetation was dominated by grass and sedge species, as is typical in this northern mixed grass prairie $[22,27,28]$. An average of $\sim 88 \%$ of live vegetation hits were grasses and sedges. Abundant grasses and sedges were blue grama (Buteloua gracilis), western wheatgrass (Agropyron smithii), junegrass (Koeleria macrantha), and threadleaf sedge (Carex filifolia). The most abundant forb was the relatively ephemeral exotic common dandelion (Taraxacum officinale), which is frequently present in native dominated grasslands throughout the United States. Fringed sage (Artemisia frigida), scarlet globemallow (Sphaeralcea coccinea), and phlox (Phlox spp.) were other relatively common forbs.

Egg-overwintering grasshopper species richness ranged from 11 to 27 across sampling sites in a given year, with a mean species richness of 18 (Table 1). A total of
TABLE 2: Egg-overwintering grasshopper species caught in sweep samples in 2001 and 2002.

\begin{tabular}{|c|c|c|}
\hline Species & 2001 & 2002 \\
\hline Ageneotettix deorum & 1,553 & 2,374 \\
\hline Melanoplus sanguinipes & 1,162 & 1,631 \\
\hline Phoetaliotes nebrascensis & 863 & 1,084 \\
\hline Opeia obscura & 575 & 668 \\
\hline Encoptolophus costalis & 490 & 590 \\
\hline Philbostroma quadrimaculatum & 487 & 720 \\
\hline Melanoplus gladstoni & 411 & 314 \\
\hline Melanoplus femurrubrum & 343 & 490 \\
\hline Melanoplus infantilis & 273 & 387 \\
\hline Orphulella speciosa & 206 & 277 \\
\hline Trachyrhachys kiowa & 165 & 281 \\
\hline Amphitornus coloradus & 140 & 185 \\
\hline Melanoplus dawsoni & 128 & 350 \\
\hline Aulocara femoratum & 126 & 176 \\
\hline Hypochlora alba & 115 & 152 \\
\hline Melanoplus packardii & 111 & 185 \\
\hline Melanoplus keeleri & 109 & 205 \\
\hline Aeropedellus clavatus & 92 & 197 \\
\hline Spharagemon equale & 36 & 64 \\
\hline Arphia pseudonietana & 33 & 68 \\
\hline Aulocara ellioti & 31 & 64 \\
\hline Melanoplus confusus & 24 & 39 \\
\hline Mermiria bivittata & 16 & 19 \\
\hline Hadrotettix trifasciatus & 16 & 24 \\
\hline Melanoplus bivittatus & 14 & 51 \\
\hline Hesperotettix viridis & 12 & 17 \\
\hline Melanoplus differentialis & 10 & 0 \\
\hline Dissosteira carolina & 8 & 2 \\
\hline Metator pardalinus & 7 & 36 \\
\hline Dactylotum bicolor & 1 & 1 \\
\hline Total caught & 9,236 & 13,590 \\
\hline
\end{tabular}

34 egg-overwintering grasshopper species were collected (Table 2). Mean grasshopper species richness per site was slightly higher than Kemp [29] and Joern [4], while total species richness was within the range observed in other similar studies in the western US (e.g., [4, 29-31]). Average grasshopper density across sites was 7.4 per $\mathrm{m}^{2}$, with a low of 1.9 and a maximum of 20.8 per $\mathrm{m}^{2}$ at a given site. Relative to long-term grasshopper densities in the area, the densities were not exceptionally high. Just prior to this study, grasshopper densities were documented at 40 and 130 per square meter $[18,19]$. However, grasshopper densities were much lower during a five-year period immediately following this study [17].

Common grasshopper species are presented in Table 2. Plant diversity did not affect grasshopper abundance (Table 3), similar to the findings of Joern [10] in tallgrass prairie. There was no effect of plant species richness on grasshopper species richness in either year (Figure 1, Table 3). Although several significant associations were 
TABLE 3: Results from regression analyses of plant species richness, live cover percentage, Shannon diversity, and Simpson evenness on grasshopper abundance and diversity. Regression equations are provided for results with a $P$ value less than .1.

\begin{tabular}{|c|c|c|}
\hline Independent (plant) & Dependent (grasshopper) & Statistical data \\
\hline \multicolumn{3}{|l|}{ A. 2001} \\
\hline \multirow{4}{*}{ Species richness } & Species richness & $R^{2}=0.002, P=.84$ \\
\hline & Shannon diversity & $Y=1.70+0.055 X ; R^{2}=0.17, P=.057$ \\
\hline & Simpson evenness & $Y=0.215+0.024 X, R^{2}=0.19, P=.045$ \\
\hline & Abundance & $Y=8.6-0.32 X ; R^{2}=0.02, P=.5$ \\
\hline \multirow{4}{*}{ Shannon diversity } & Species richness & $R^{2}<0.001, P=.99$ \\
\hline & Shannon diversity & $R^{2}=0.1, P=.16$ \\
\hline & Simpson evenness & $R^{2}=0.06, P=.26$ \\
\hline & Abundance & $R^{2}=0.03, P=.43$ \\
\hline \multirow{4}{*}{ Live cover } & Species richness & $Y=8.23+0.292 X ; R^{2}=0.4 ; P=.001$ \\
\hline & Shannon diversity & $R^{2}=0.1, P=.15$ \\
\hline & Simpson evenness & $R^{2}=0.016, P=.6$ \\
\hline & Abundance & $Y=-3.37+0.329 X ; R^{2}=0.2, P=.036$ \\
\hline \multirow{4}{*}{ Evenness } & Species richness & $R^{2}=0.003, P=.8$ \\
\hline & Shannon diversity & $R^{2}=0.11, P=.12$ \\
\hline & Simpson evenness & $R^{2}=0.05, P=.33$ \\
\hline & Abundance & $R^{2}=0.024, P=.5$ \\
\hline \multicolumn{3}{|l|}{ B. 2002} \\
\hline \multirow{4}{*}{ Species richness } & Species richness & $R^{2}=0.01, P=.6$ \\
\hline & Shannon diversity & $R^{2}=0.08, P=.2$ \\
\hline & Simpson evenness & $R^{2}=0.09, P=.15$ \\
\hline & Abundance & $R^{2}=0.06, P=.25$ \\
\hline \multirow{4}{*}{ Shannon diversity } & Species richness & $Y=24.01-3.882 X, R^{2}=0.19, P=.04$ \\
\hline & Shannon diversity & $R^{2}=0.05, P=.32$ \\
\hline & Simpson evenness & $Y=0.168+157 X, R^{2}=0.21, P=.03$ \\
\hline & Abundance & $Y=15.0-6.96 X, R^{2}=0.24, P=.015$ \\
\hline \multirow{4}{*}{ Live cover } & Species richness & $R^{2}=0.02, P=.53$ \\
\hline & Shannon diversity & $Y=1.8+0.014 X, R^{2}=0.2, P=.03$ \\
\hline & Simpson evenness & $Y=0.158+0.008 X, R^{2}=0.212, P=.027$ \\
\hline & Abundance & $R^{2}=0.003, P=.8$ \\
\hline \multirow{4}{*}{ Evenness } & Species richness & $Y=15.4-9.6 X, R^{2}=0.25, P=.016$ \\
\hline & Shannon diversity & $R^{2}=0.035, P=.39$ \\
\hline & Simpson Evenness & $Y=0.151+0.348 X, R^{2}=0.22, P=.025$ \\
\hline & Abundance & $Y=15.7-15.36 X, R^{2}=0.26, P=.014$ \\
\hline
\end{tabular}

found through the regression analyses, results differed greatly between years (Figure 1, Table 3). Grasshopper community Shannon diversity and Simpson evenness were positively associated with plant species richness in 2001, indicating that sites with increased plant diversity had a more evenly distributed grasshopper community assemblage. By contrast, grasshopper species richness, evenness, and abundance were all positively associated with Shannon diversity of plants in 2002. Grasshopper species richness and abundance were positively associated with the percentage of live plant cover in 2001, while diversity and evenness of the grasshopper community were positively associated with live cover in 2002. Grasshopper species richness, evenness, and abundance were all positively associated with plant species evenness in 2002 . As significant relationships differed almost entirely between years, it appears unlikely that either plant species richness or diversity was a strong causative factor responsible for observed significant statistical results. However, a consistent result in both years was that grasshopper species richness was not positively associated with plant species richness (Figure 1). Although specialist grasshopper richness would be expected to increase with plant species richness, this is a highly grass dominated system with many generalist feeding grasshoppers [32].

Strong conclusions regarding the nature of the relationship between plant species diversity and grasshopper species 


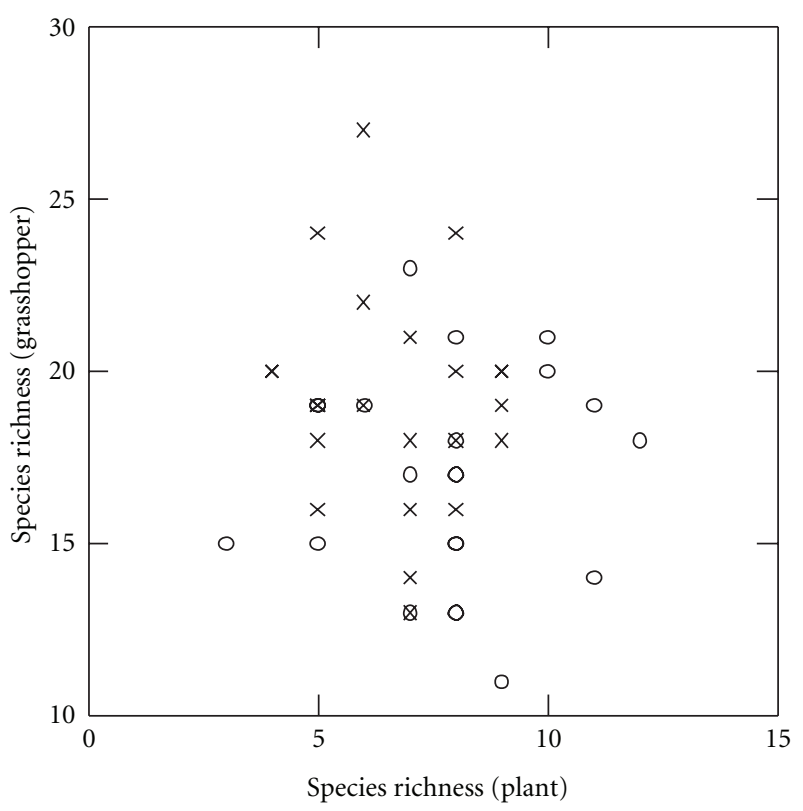

○ 2001

$\times 2002$

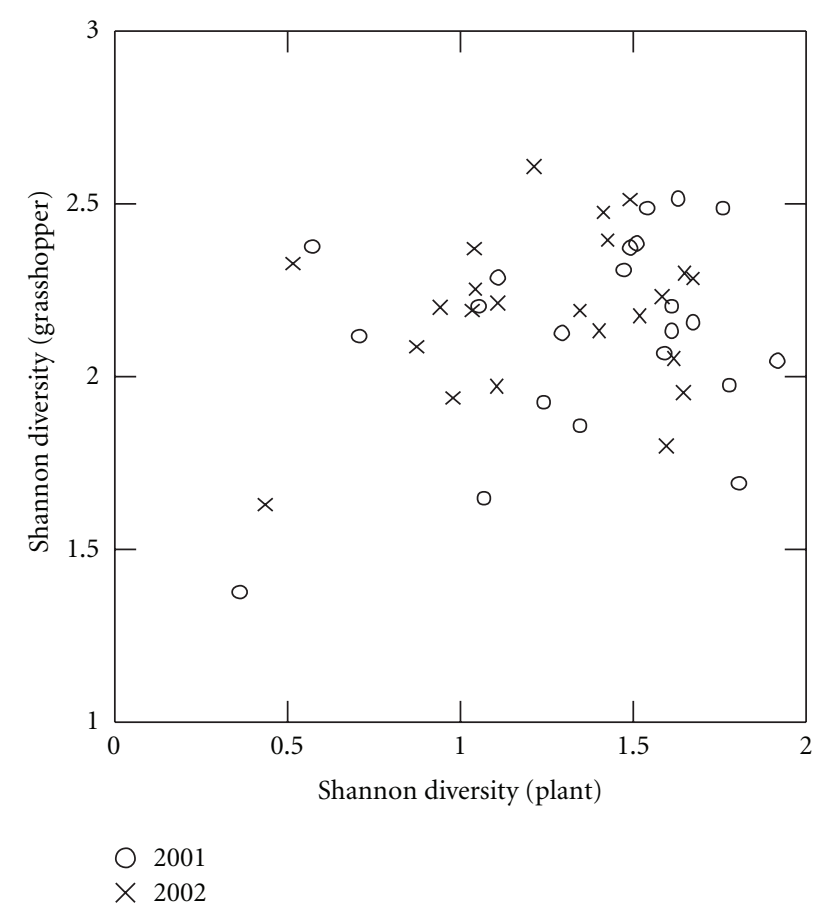

(b)

FIGURE 1: Relationship in 2001 and 2002 between (a) species richness of grasshoppers and plants and (b) Shannon diversity of grasshoppers and plants.

diversity in North America remain difficult. In a study across an elevational gradient in Montana, Wachter et al. [13] found no significant relationships between plant cover or species richness and grasshopper species richness, diversity, and abundance. By contrast, Fielding and Brusven [14] found a positive correlation between plant and grasshopper species richness in semiarid rangeland. In a more productive tallgrass prairie system, Evans [12] and Joern [4] also found grasshopper species richness was positively related with plant species richness. Plant species richness was similar in the study by Joern [4] and higher in the study by Fielding and Brusven [14]. In this study, as well as in Joern [4] and Fielding and Brusven [14] where positive relationships were found between grasshopper and plant species richness, the ratio of grasshopper species to plant species was typically greater than 1.0. In a desert environment in the southwestern US with low grasshopper species diversity but several specialist species, Otte [9] found a positive relationship between grasshopper and plant species diversity when the ratio of grasshopper species to plant species was always less than 0.43 . As a result, the lack of a relationship between plant and grasshopper species richness does not appear a result of grasshopper or plant species richness varying by orders of magnitude from other studies. As pointed out by Fielding and Brusven [14], "grasshopper species richness is probably not a simple function of plant species richness."

Grasshopper populations are highly cyclical in this area and respond to weather conditions $[18,19,27]$. Drought has been shown to reduce grasshopper species diversity at nearby sites in eastern Montana [33], while a late summer rainfall event led to a three-fold increase in grasshopper densities in the following year [19]. Precipitation patterns during 2001 and 2002 were not extreme outliers relative to longterm averages. Given the variation in correlations between years, longer-term sampling would be required to determine if consistent patterns emerge and if patterns vary with precipitation or densities. Grasshoppers were relatively abundant during the period of the study and density dependent factors could have influenced grasshopper or plant species composition. Both intraspecific and intraspecific exploitative competition can play an important role in grasshopper population dynamics and plant composition [19, 34, 35]. In addition, preferential grasshopper herbivory has been shown to influence plant species diversity in study area when abundant [17]. Although grasshopper herbivory could have removed all visible plant material prior to plant sampling, vegetation sampling occurred relatively early in the summer.

Many of the hypotheses proposed to explain positive relationships between plant and herbivorous insect diversity are based on the fact that many insects are relatively specialized [5]. However, many grasshopper species are generalists $[17,32]$. As a result, inconsistent and weak relationships could be reflective of the ability of generalist grasshoppers to feed on numerous plant species or could be an artifact of difficulties in sampling rare species [5]. Haddad et al. [5] conducted an 11-year experiment manipulating plant diversity and examining effects on arthropod herbivores and predators and found herbivore arthropod species richness was strongly positively related to plant species richness only when examining cumulative species richness across the 
11 year time period. This illustrates the potential importance of longer term sampling when examining relationships between plant and grasshopper species richness.

The results from this study also support Kemp et al. [36], who argued that plant species richness is too coarse grained a measure to lead to accurate predictions of grasshopper species richness. Although plant community associations are likely to be a better predictor of grasshopper species richness than plant species richness in a variety of ecosystems $[36,37]$, a potential constraint is that ordination techniques may result in system specific conclusions regarding relationships between plant communities and grasshopper species.

\section{Acknowledgments}

The author thanks Nicole Davidson for assistance in data organization and Donovan Craig for setting up sampling sites and collecting data.

\section{References}

[1] E. W. Evans, "Fire as a natural disturbance to grasshopper assemblages of tallgrass prairie," Oikos, vol. 43, no. 1, pp. 916, 1984.

[2] W. P. Kemp, S. J. Harvey, and K. M. O’Neill, "Patterns of vegetation and grasshopper community composition," Oecologia, vol. 83, no. 3, pp. 299-308, 1990.

[3] N. M. Haddad, D. Tilman, J. Haarstad, M. Ritchie, and J. M. H. Knops, "Contrasting effects of plant richness and composition on insect communities: a field experiment," American Naturalist, vol. 158, no. 1, pp. 17-35, 2001.

[4] A. Joern, "Disturbance by fire frequency and bison grazing modulate grasshopper assemblages in tallgrass prairie," Ecology, vol. 86, no. 4, pp. 861-873, 2005.

[5] N. M. Haddad, G. M. Crutsinger, K. Gross, J. Haarstad, J. M. H. Knops, and D. Tilman, "Plant species loss decreases arthropod diversity and shifts trophic structure," Ecology Letters, vol. 12, no. 10, pp. 1029-1039, 2009.

[6] B. A. Hawkins and E. E. Porter, "Does herbivore diversity depend on plant diversity? The case of California butterflies," American Naturalist, vol. 161, no. 1, pp. 40-49, 2003.

[7] A. G. Vestal, "Local distribution of grasshoppers in relation to plant associations," Biological Bulletin, vol. 25, pp. 141-180, 1913.

[8] S. Torrusio, M. M. Cigliano, and M. L. De Wysiecki, "Grasshopper (Orthoptera: Acridoidea) and plant community relationships in the Argentine pampas," Journal of Biogeography, vol. 29, no. 2, pp. 221-229, 2002.

[9] D. Otte, "Species richness patterns of New World desert grasshoppers in relation to plant diversity," Journal of Biogeography, vol. 3, pp. 197-209, 1976.

[10] A. Joern, "Variation in grasshopper (Acrididae) densities in response to fire frequency and bison grazing in tallgrass prairie," Environmental Entomology, vol. 33, no. 6, pp. 1617$1625,2004$.

[11] D. H. Branson, A. Joern, and G. A. Sword, "Sustainable management of insect herbivores in grassland ecosystems: new perspectives in grasshopper control," BioScience, vol. 56, no. 9, pp. 743-755, 2006.

[12] E. W. Evans, "Grasshopper (Insecta: Orthoptera: Acrididae) assemblages of tallgrass prairie: influences of fire frequency, topography, and vegetation," Canadian Journal of Zoology, vol. 66, no. 7, pp. 1495-1501, 1988.

[13] D. H. Wachter, K. M. O’Neill, and W. P. Kemp, “Grasshopper (Orthoptera: Acrididae) communities on an elevational gradient in southwestern Montana," Journal of the Kansas Entomological Society, vol. 71, no. 1, pp. 35-43, 1998.

[14] D. J. Fielding and M. A. Brusven, "Grasshopper (Orthoptera: Acrididae) community composition and ecological disturbance on southern Idaho rangeland," Environmental Entomology, vol. 22, no. 1, pp. 71-81, 1993.

[15] G. E. Belovsky, "Do grasshoppers diminish grassland productivity? A new perspective for control based on conservation," in Grasshoppers and Grassland Health: Managing Grasshopper Outbreaks without Risking Envionmental Disaster, J. A. Lockwood, A. V. Latchininsky, and M. G. Sergeev, Eds., pp. 7-29, Kluwer Academic Publishers, Boston, Mass, USA, 2000.

[16] D. C. Thompson, K. C. Mcdaniel, and L. A. Torell, "Feeding by a native grasshopper reduces broom snakeweed density and biomass," Journal of Range Management, vol. 49, no. 5, pp. 407-412, 1996.

[17] D. H. Branson and G. A. Sword, "Grasshopper herbivory affects native plant diversity and abundance in a grassland dominated by the exotic grass Agropyron cristatum," Restoration Ecology, vol. 17, no. 1, pp. 89-96, 2009.

[18] J. A. Onsager, "Suppression of grasshoppers in the Great Plains through grazing management," Journal of Range Management, vol. 53, no. 6, pp. 592-602, 2000.

[19] D. H. Branson, "Influence of a large late summer precipitation event on food limitation and grasshopper population dynamics in a northern great plains grassland," Environmental Entomology, vol. 37, no. 3, pp. 686-695, 2008.

[20] R. F. Chapman, "Food selection," in Biology of Grasshoppers, R. F. Chapman and A. Joern, Eds., pp. 39-72, John Wiley and Sons, New York, NY, USA, 1990.

[21] R. F. Chapman and G. A. Sword, "Polyphagy in the acridomorpha," in The Bionomics of Grasshoppers, Katydids, and Their Kin, S. K. Gangwere, M. C. Muralirangan, and M. Muralirangan, Eds., pp. 183-195, CAB International, New York, NY, USA, 1997.

[22] J. Butler, H. Goetz, and J. L. Richardson, "Vegetation and soil-landscape relationships in the North Dakota Badlands," American Midland Naturalist, vol. 116, no. 2, pp. 378-386, 1986.

[23] J. A. Onsager and J. E. Henry, "A method for estimating the density of rangeland grasshoppers (Orthoptera, Acrididae) in experimental plots," Acrida, vol. 6, pp. 231-237, 1977.

[24] J. S. Berry, J. A. Onsager, and W. P. Kemp, "Assessing rangeland grasshopper populations," in Integrated Pest Management User Handbook, USDA-APHIS Technical Bulletin no. 1809, pp. VI.10-1-VI.10-12, 2000.

[25] J. A. Onsager, "A note on the Poisson distribution in integrated pest management," Bulletin of the Entomological Society of America, vol. 27, pp. 119-120, 1981.

[26] A. E. Magurran, Measuring Biological Diversity, Blackwell Publishing, Malden, Mass, USA, 2004.

[27] D. H. Branson and G. A. Sword, "An experimental analysis of grasshopper community responses to fire and livestock grazing in a northern mixed-grass prairie," Environmental Entomology, vol. 39, no. 5, pp. 1441-1446, 2010.

[28] L. M. Clark, Late-season burning and grazing interactions on mixed-grass prairie and woody draws, M.S. thesis, North Dakota State University, 2006.

[29] W. P. Kemp, “Temporal variation in rangeland grasshopper (Orthoptera: Acrididae) communities in the steppe region of 
Montana, USA," Canadian Entomologist, vol. 124, no. 3, pp. 437-450, 1992.

[30] A. Joern and K. P. Pruess, “Temporal constancy in grasshopper assemblies ( Orthoptera: Acrididae)," Ecological Entomology, vol. 11, no. 4, pp. 379-385, 1986.

[31] J. L. Capinera and D. C. Thompson, "Dynamics and structure of grasshopper assemblages in shortgrass prairie," Canadian Entomologist, vol. 119, no. 6, pp. 567-575, 1987.

[32] R. E. Pfadt, "Field guide to common western grasshoppers," in Wyoming Agricultural Experiment Station Bulletin 912, 3rd edition, 2002.

[33] W. P. Kemp and M. M. Cigliano, "Drought and rangeland grasshopper species diversity," Canadian Entomologist, vol. 126, no. 4, pp. 1075-1092, 1994.

[34] G. E. Belovsky and J. B. Slade, "Dynamics of two Montana grasshopper populations: relationships among weather, food abundance and intraspecific competition," Oecologia, vol. 101, no. 3, pp. 383-396, 1995.

[35] D. H. Branson, "Reproduction and survival in Melanoplus sanguinipes (Orthoptera: Acrididae) in response to resource availability and population density: the role of exploitative competition," Canadian Entomologist, vol. 135, no. 3, pp. 415426, 2003.

[36] W. P. Kemp, M. M. Cigliano, K. M. O’Neill, and S. Torrusio, "Field-scale variations in plant and grasshopper communities: a GIS-based assessment," Transactions in GIS, vol. 6, no. 2, pp. 115-133, 2002.

[37] A. P. Schaffers, I. P. Raemakers, K. V. Sykora, and C. J. F. Ter Braak, "Arthropod assemblages are best predicted by plant species composition," Ecology, vol. 89, no. 3, pp. 782-794, 2008. 

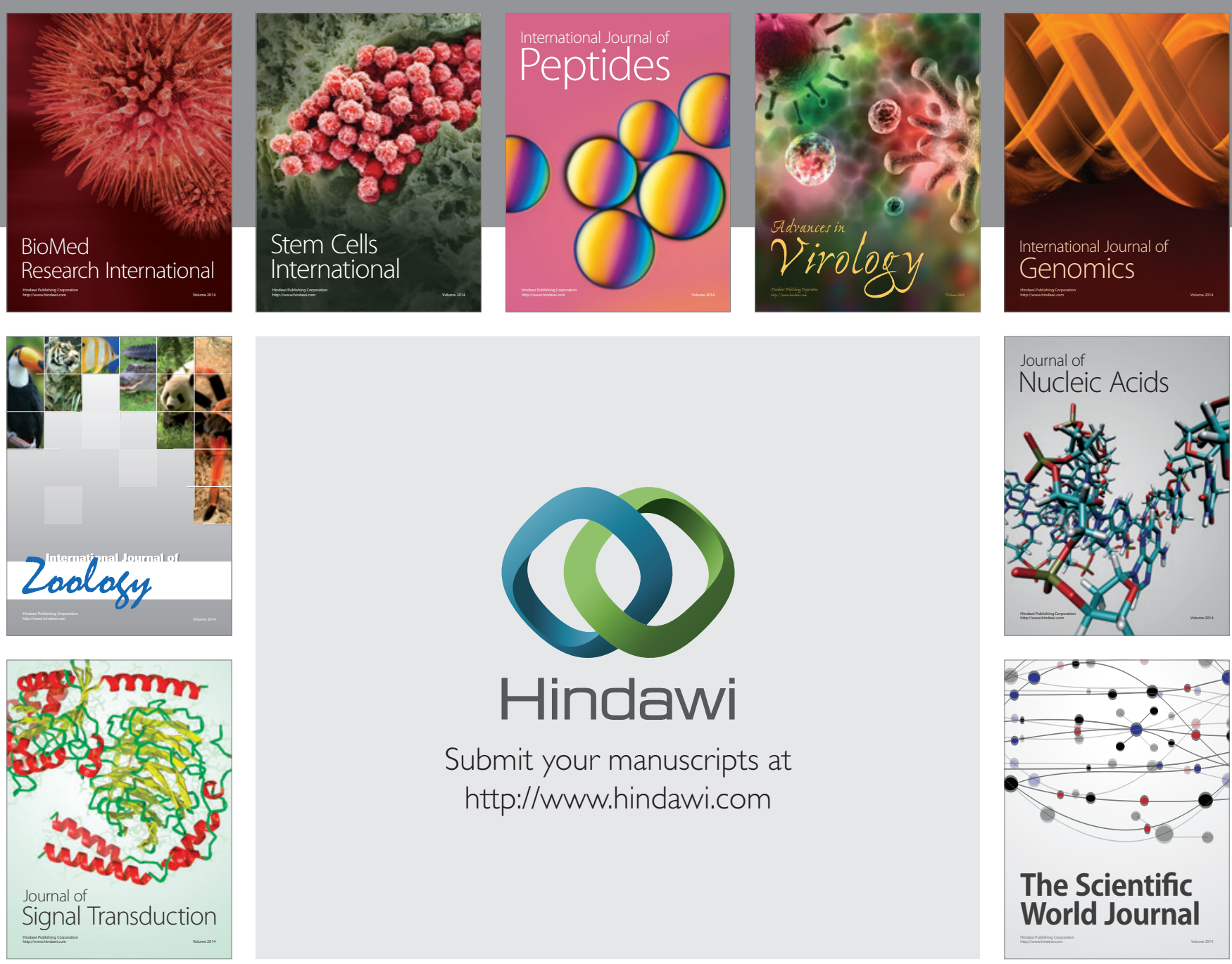

Submit your manuscripts at

http://www.hindawi.com
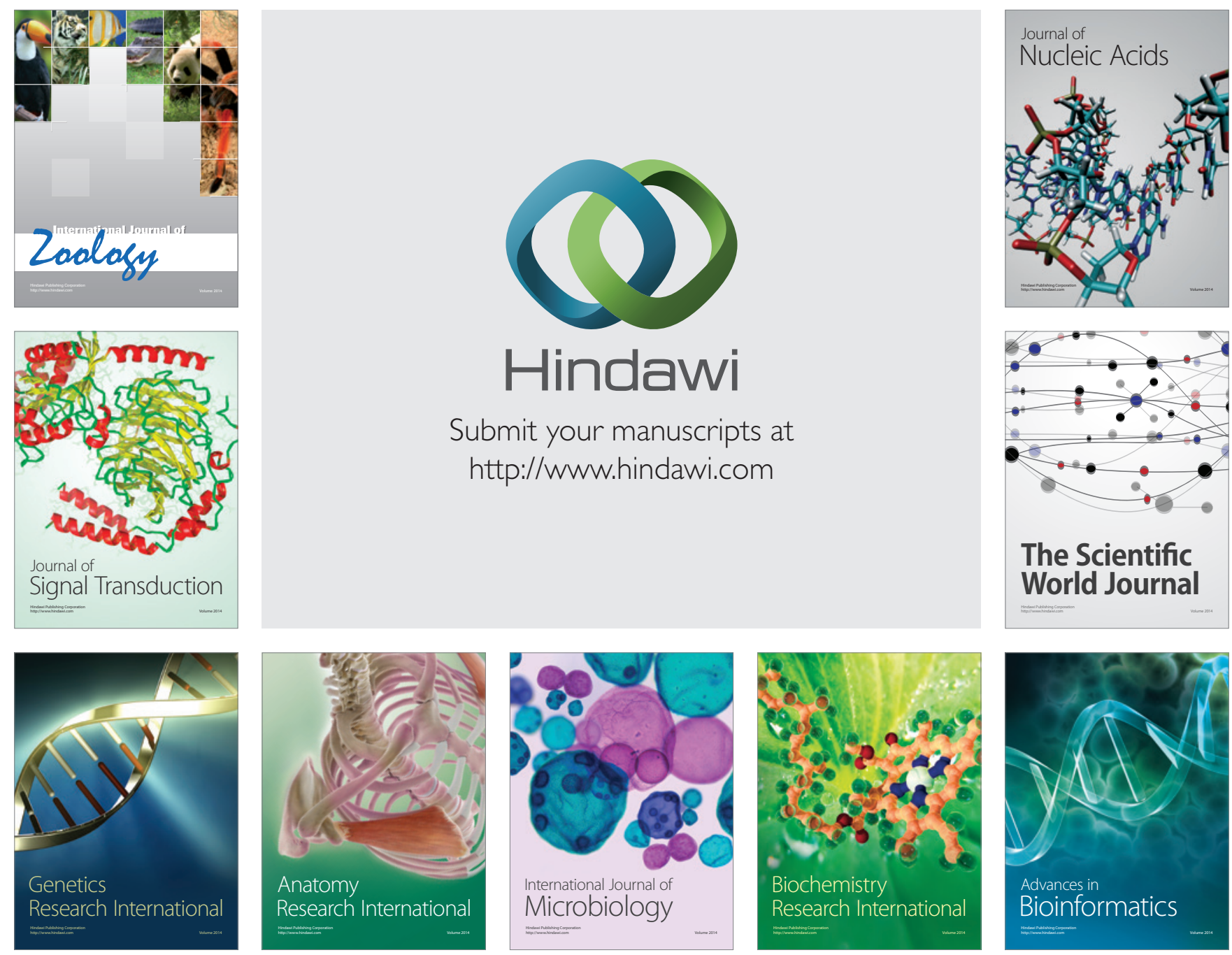

The Scientific World Journal
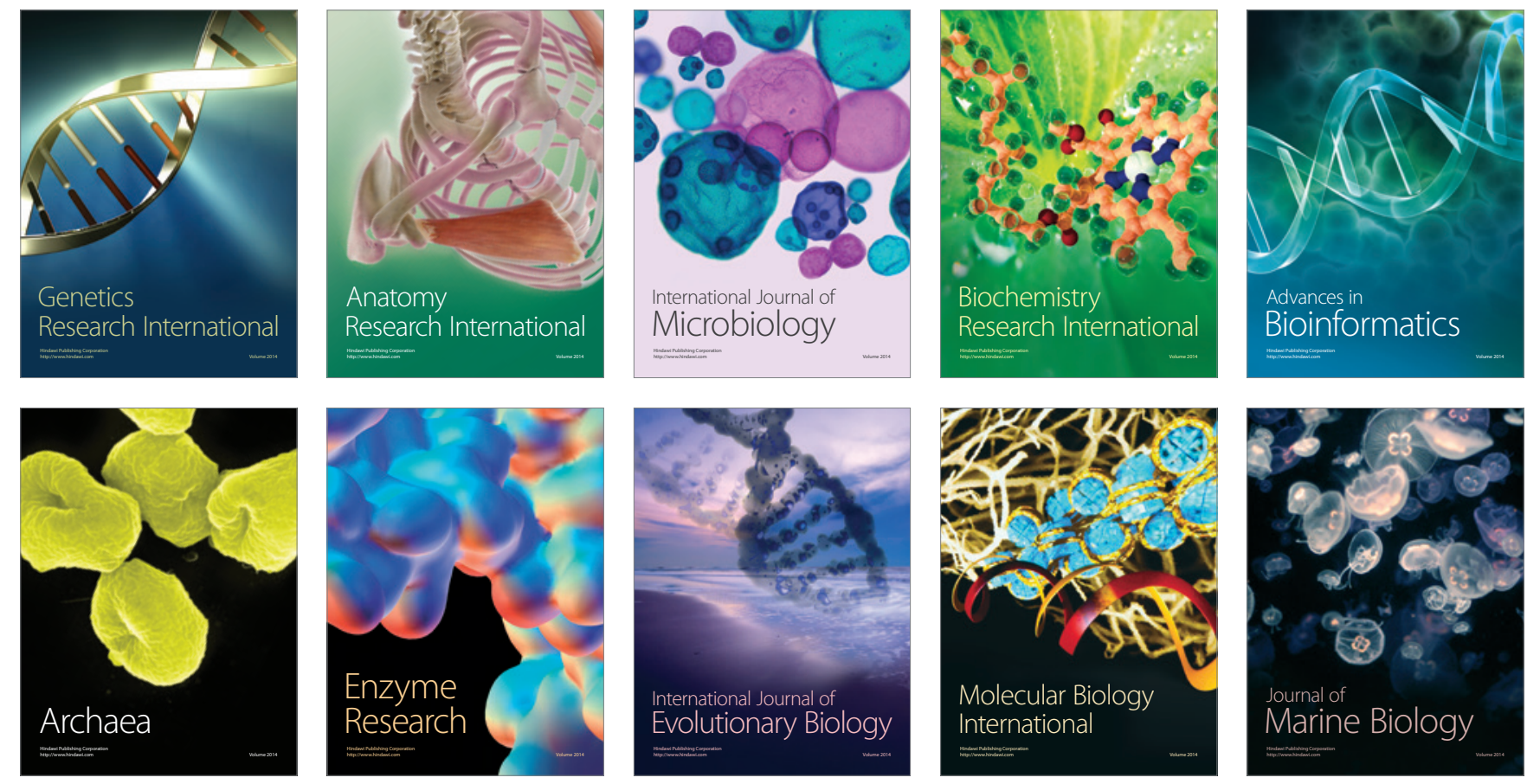